Ritrýnd grein birt 31. desember 2021

\title{
Svefnlengd íslenskra grunnskólanema
}

\author{
Guðrún Kristjánsdóttir, Rúnar Vilhjálmsson og Vaka Rögnvaldsdóttir \\ Abstract $\quad$ Um höfunda About the authors $\quad$ Heimildir
}

Prátt fyrir fjölda svefnrannsókna á undanförnum árum er enn margt á huldu um útbreiðslu svefnvenja meðal ungmenna. Nægur nætursvefn er mikilvægur fyrir proska, heilsu og námsgetu ungs fólks. Markmið rannsóknarinnar var að skoða hvort svefnlengd íslenskra skólanema samræmdist svefnráðleggingum, hver meðalsvefnlengd nemendanna væri og hver munur væri á tíðni ráðlagðs svefns og svefnlengd milli einstakra hópa nemenda.

Landskönnunin „Heilsa og lífskjör skólanema“ (HBSC) fór fram árið 2018 meðal nemenda í 6., 8. og 10. bekk. Alls svöruðu 7.159 nemendur á landinu öllu stöðluðum spurningalista. Nemendurnir voru meðal annars spurðir um háttatíma sinn og fótaferðartíma. Viðmið um nægilegan svefn voru borin saman við alpjóðlegar ráðleggingar ungmenna í 6. bekk (9-11 klst./nóttu), og fyrir nemendur í 8. og 10. bekk (8-10 klst./ nóttu).

Niðurstöður sýndu að um 30\% nemenda í 6., 8. og 10. bekk ná ekki viðmiðum um ráðlagða svefnlengd á virkum dögum. Piltar náðu síður ráðlagðri svefnlengd en stúlkur, og 10. bekkingar mun síður en nemendur í yngri bekkjardeildum. Nemendur sem áttu foreldra af erlendum uppruna sváfu skemur og náðu síður ráðlögðum svefni en aðrir nemendur. Nemendur sem bjuggu með báðum lífforeldrum sínum sváfu lengur og fengu oftar ráðlagðan svefn en nemendur í öðrum fjölskyldugerðum. Pá kom í ljós að nemendur á höfuðborgarsvæðinu sváfu lengur og náðu frekar ráðlögðum svefni en nemendur af landsbyggðinni. Ekki var marktækur munur á lengd nætursvefns eftir efnahag fjölskyldunnar.

Umtalsverður hluti íslenskra ungmenna nær ekki nægum nætursvefni. Mikilvægt er að gefa nánari gaum að nætursvefni íslenskra ungmenna, einkum meðal peirra ungmenna sem fá hvað stystan nætursvefn.

Efnisorð: Svefn, svefnlengd, háttatími, ungmenni, félagsleg staða

\section{Inngangur}

Svefn er mikilvægur fyrir heilsu og líðan fólks á öllum aldri (Mignot, 2008). Rannsóknir á svefni sýna tengsl við mikilvæga heilsutengda pætti svo sem líkamlega, (Megdal og Schernhammer, 2007), andlega og félagslega heilsu, almenn lífsgæði (Eaton o.fl., 2010; National Sleep Foundation, 2006) og almennt fæðuval (Beebe o.fl., 2013; Chapman o.fl., 2012; Chaput, 2014; Chaput og St-Onge, 2014; Spaeth o.fl., 2013; Weiss o.fl., 2010). Endurnærandi nætursvefn er hluti af æskilegri heilsuhegðun í takt við góða næringu og hreyfingu (Chaput o.fl., 2018).

Unglingsár eru mikilvæg mótunarár líkamlegrar og andlegrar heilsu (Tarokh o.fl., 2016) og er svefn 
talinn vera einn af hornsteinum góðrar heilsu ungmenna. Alpjóðlegar ráðleggingar fyrir svefnheilsu ungmenna miða við að skólabörn (6-13 ára) sofi 9-11 klukkustundir á nóttu og ungmenni (14-17 ára) sofi 8-10 klukkustundir á nóttu (Hirshkowitz o.fl., 2015). Pá er einnig mælt með pví að halda reglu á svefntíma skóladaga sem og frídaga (Gruber o.fl., 2014) til að standa vörð um svefnheilsu. Við kynproskaaldur seinkar líffræðilegri klukku (líkamsklukku) ungmenna, en hún samstillir hringrás líffræðilegra pátta sem eiga sér stað yfir sólarhringinn (líkamshita, blóðprýstings og hormóna). Seinkun líkamsklukkunnar seinkar kvöldsyfju og eykur par með pörf fyrir að sofa lengur á morgnana (Gruber o.fl., 2014; Phillips, 2009; Wright o.fl., 2012). Seinkun á háttatíma og skóli snemma morguns eru peir pættir sem hafa hve mest áhrif á svefnlengd ungmenna (Wheaton o.fl., 2015). Rannsóknir sýna að stuttur nætursvefn er algengur meðal barna og ungmenna, en svefnlengd hefur verið að styttast undanfarna áratugi (Keyes o.fl., 2015; Matricciani o.fl., 2012; Van Cauter o.fl., 2008). Talið er að um 30-70\% evrópskra og amerískra ungmenna búi við lakar svefnvenjur með tilliti til svefnlengdar, svefngæða og tímasetningar svefns (Gradisar o.fl., 2011) og aðeins 30\% amerískra ungmenna ná 8-10 klukkustunda nætursvefni á skóladögum (Eaton o.fl., 2010; National Sleep Foundation, 2006). Í íslenskri rannsókn á svefnlengd ungmenna, par sem gögnum var safnað með hreyfimælum, kemur fram að 15-16 ára ungmenni sofa einungis 6,2 klukkustundir á skólanóttum og um klukkustund lengur á frídögum (Rognvaldsdottir o.fl., 2017). Í eldri íslenskri rannsókn (Thorleifsdottir o.fl., 2002), sem byggð er á gögnum úr spurningalistum og svefndagbókum, kemur fram að íslensk ungmenni hafi styttri nætursvefn en evrópsk ungmenni (Thorleifsdottir o.fl., 2002). Í peirri sömu rannsókn sváfu ungmenni, 16-19 ára, búsett á landsbyggðinni, lengur á skóladögum og styttra á frídögum en ungmenni búsett á höfuðborgarsvæðinu. Í niðurstöðum alpjóðlegrar samanburðarrannsóknar (Health Behavior in School-aged Children - HBSC 2018) kemur fram að svefnlengd íslenskra ungmenna er mjög ápekk svefnlengd ungmenna annarra Evrópulanda á skóladögum og frídögum (Gariepy o.fl., 2020).

Tengsl hafa fundist milli styttri nætursvefns meðal ungmenna og lakari heilsu, bæði efnaskipta(Gangwisch o.fl., 2010) og andlegrar heilsu (Zhang o.fl., 2017) og einnig vitrænnar getu (Dahl, 1996). Pversniðsrannsóknir á svefnlengd hafa sýnt að styttri svefn tengist slakari námsárangri barna (Kelly o.fl., 2013) og ungmenna (Phillips o.fl., 2017). Pá hefur stutt svefnlengd verið talin undanfari depurðar meðal ungs fólks (Conklin o.fl., 2018). Úr niðurstöðum í íslensku landskönnuninni „Heilsa og lífskjör skólanema” (sem er hluti af HBSC-samanburðar-rannsókninni 2018) kemur fram að svefnörðugleikar skýri hvað mest aukningu á depurð meðal ungmenna (Ársæll Arnarsson, 2019).

Ólík fjölskyldugerð og félags- og efnahagsstaða fjölskyldunnar eru pekktar spábreytur fyrir almennt heilsufar (Adler o.fl., 1994) og pví er mikilvægt að skoða tengsl svefns ungmenna við stöðu fjölskyldunnar, en próun svefnvenja er ekki síst viðkvæm á pessu aldurstímabili (Felden, Leite, Rebelatto, Andrade og Beltrame, 2015). Rannsóknir á svefnlengd ungmenna í tengslum við efnahagslega stöðu fjölskyldu (Keyes o.fl., 2015) eða pjóðernishópa (Jarrin o.fl., 2014) sýna mismunandi áhrif á svefnlengd. Samantektarrannsókn bendir til pess að bág efnahagsleg staða fjölskyldu hafi neikvæð áhrif á svefnlengd og svefngæði ungmenna (Felden o.fl., 2015) og að svefnvandi hafi tengsl við efnahagslega stöðu fjölskyldu en sé síður bundinn minnihlutahópum, svo sem pjóðernishópum (Roberts o.fl., 2006).

Mikilvægt er að fylgjast með stöðu og próun svefnlengdar og svefntíma meðal ungmenna á tímum par sem sjónvarpsdagskrá og annað skemmtiefni á netinu er aðgengilegt allan sólarhringinn. Prátt fyrir fjölda svefnrannsókna á undanförnum árum er enn margt á huldu um útbreiðslu svefnvenja meðal ungmenna. Með pví að kortleggja svefnlengd ungmenna eftir pekktum áhrifapáttum er unnt að vinna betur að fræðslu og meðvitund í samfélaginu um mikilvægi svefns fyrir heilsu ungmenna.

Markmið pessarar rannsóknar var að skoða hvort svefnlengd íslenskra grunnskólanema samræmdist viðurkenndum svefnráðleggingum, hver meðalsvefnlengd nemendanna væri og hver munur væri á tíðni ráðlagðs svefns og svefnlengdar milli einstakra hópa nemenda, p.e. eftir aldri, kyni, uppruna, búsetu, efnahagsstöðu og fjölskyldugerð. 


\section{Efniviður og aðferðir}

Unnið var úr gögnum úr landskönnuninni „Heilsa og lífskjör skólanema“ sem tengist fjölpjóðlegu samstarfsverkefni í um 40 löndum (Health Behavior in School-aged Children - HBSC) með stuðningi Alpjóðaheilbrigðismálastofnunarinnar (WHO). Landskönnunin fór fram árið 2018 par sem ungmennin, nemendur í 6., 8. og 10. bekk í almennum grunnskólum í landinu, tóku pátt. Nafnlausir staðlaðir spurningalistar um aðstæður, lifnaðarhætti og heilsufar voru lagðir fyrir nemendurna í skólastofu á skólatíma. Á fyrstu síðu spurningalistans var nemendum meðal annars heitið nafnleynd og bent á að peim væri ekki skylt að svara spurningalistanum í heild eða einstökum spurningum (Einar B. Porsteinsson og Ársæll Arnarsson, 2018). Landskönnunin var tilkynnt til Persónuverndar og leyfi fengin til fyrirlagnar hjá skólastjórnendum. Alls tóku 7.159 skólanemar pátt í landskönnuninni. Svarhlutfall í pátttökuskólunum var í heild yfir 80\%, en fjöldi svarenda var 55,5\% af heildarfjölda nemenda í öllum grunnskólum landsins. Aldurs- og kynjasamsetning svarendahópsins samsvaraði vel aldurs- og kynjasamsetningu íslenskra grunnskólanema í 6., 8. og 10. bekk.

\section{Svefnlengd}

Til pess að grafast fyrir um svefnvenjur voru nemendurnir fyrst spurðir: „Hvenær ferðu venjulega að sofa ef pað er skóli daginn eftir?" Svarmöguleikar voru á hálftíma millibili frá „Fyrir kl. 21.00“ til „02.00 eða seinna“. Peir voru einnig spurðir: „Hvenær vaknarðu yfirleitt ef pú átt að fara í skólann?“ Svarmöguleikar voru á hálftíma millibili frá „ekki seinna en 05.00 “ til „10.00 eða seinna“. Svefnlengd var reiknuð, í heilum og hálfum klukkustundum, sem mismunur á tímanum milli pess hvenær farið er að sofa og hvenær farið eru á fætur. Svefnlengd var borin saman við alpjóðlegar ráðleggingar um svefnlengd sem eru 9-11 klst. á nóttu fyrir nemendur í 6. bekk, og 8-10 klst. á nóttu fyrir nemendur í 8. og 10. bekk (Hirshkowitz o.fl., 2015).

\section{Lýðfræðileg staða, efnahagur fjölskyldu, uppruni, fjölskyldugerð og búseta}

Nemendurnir voru spurðir um kynferði, bekkjardeild (6., 8. eða 10. bekkur) og uppruna foreldra eftir fæðingarlandi og greint á milli pess hvort báðir foreldrar, annað foreldrið, eða hvorugt foreldrið væri fætt erlendis. Einnig var spurt um fjölskyldugerð og greint á milli peirra sem bjuggu með báðum lífforeldrum, með einstæðu foreldri, í stjúpfjölskyldu, eða í öðru fjölskyldufyrirkomulagi. Pá var efnahagur fjölskyldunnar metinn með svonefndum FAS-kvarða (Family Affluence Scale, Torsheim o.fl., 2016). Efnahagskvarðinn (FAS-kvarði) var byggður á spurningum um hvort fjölskyldan ætti bíl, hvort nemandinn hefði eigið svefnherbergi, hve margar tölvur fjölskyldan ætti, hve mörg baðherbergi væru á heimilinu, hvort upppvottavél væri á heimilinu, og hve oft fjölskyldan hefði farið til útlanda sl. 12 mánuði. Stig fyrir hverja spurningu voru lögð saman í 0-13 stiga efnahagskvarða. Við tölfræðilega úrvinnslu voru stigin flokkuð og greint á milli lakrar (0-7 stig), miðlungs (8-10 stig) og hárrar (11-13 stig) efnahagsstöðu. Loks var búseta metin út frá póstnúmeri og greint á milli peirra sem bjuggu á höfuðborgarsvæðinu eða landsbyggðinni.

\section{Tölfræðileg úrvinnsla}

Munur á hlutfallstíðni peirra sem náðu viðmiðum um ráðlagða svefnlengd var metin eftir hópum nemenda (kyni, bekkjardeild, efnahag fjölskyldu, pjóðernisuppruna, fjölskyldugerð og búsetu) og greindur með Kí-kvaðrat marktektarprófi. Meðaltalsmunur á svefnlengd milli hópa var metinn með t-marktektarprófi pegar hópar eru tveir, en F-marktektarprófi pegar hópar eru fleiri. Marktektarmörk voru sett við $\mathrm{p}<0,05$. I framhaldi af framangreindum marktektarprófum var framkvæmd margpátta aðhvarfsgreining til pess að meta tengsl hreyfingar við hverja bakgrunnsbreytu að teknu tilliti til annarra bakgrunnsbreyta. Pannig var framkvæmd lógistísk aðhvarfsgreining (e. logistic regression) á tengslum bakgrunnsbreytanna við ráðlagða hreyfingu og venjuleg aðhvarfsgreining (e. ordinary least squares, OLS) á tengslum bakgrunnsbreytanna við vikudaga í líkamlegri hreyfingu. Í öllum tilvikum voru marktektarmörk miðuð við $\mathrm{p}<0,05$. 


\section{Niðurstöður}

Um 30\% ungmenna uppfylla ekki ráðleggingar um svefnlengd á virkum dögum pegar allar bekkjardeildir (6., 8. og 10. bekkur) eru skoðaðar saman. Dálkar til vinstri í Töflu 1 sýna nánar hlutfall nemenda sem náði ráđlögðum nætursvefni eftir hópum. Piltar náðu síður ráðlögðum nætursvefni en stúlkur og 10. bekkingar mun síður en nemendur í yngri bekkjardeildum. Pá var ráðlögðum svefni misskipt eftir pjóðernisuppruna foreldra, en par hallaði á nemendur sem áttu foreldra af erlendum uppruna. Einnig kom í ljós að börn sem bjuggu með báðum lífforeldrum náðu frekar ráðlögðum nætursvefni en börn í öðrum fjölskyldugerðum. Nemendur á höfuðborgarsvæðinu náðu frekar ráðlögðum nætursvefni en nemendur á landsbyggðinni. Ekki mældist munur á ráðlögðum nætursvefni eftir efnahag fjölskyldu.

Tafla 1. Ráðlagður svefn og svefnlengd í einstökum hópum nemenda (N=7159).

\begin{tabular}{|c|c|c|c|c|c|c|}
\hline & \multicolumn{3}{|c|}{ Ráðlagður svefn } & \multicolumn{3}{|c|}{ Svefnlengd (klst.) } \\
\hline & $\%$ & $\mathrm{n} / \mathrm{N}$ & $\mathrm{p}^{1}$ & Meðaltal & Staðalfrávik & $\mathrm{p}^{2}$ \\
\hline \multicolumn{7}{|l|}{ Kynferði } \\
\hline Piltur & 68,9 & $2029 / 2945$ & & 8,39 & 1,17 & \\
\hline Stúlka & 71,9 & $2191 / 3046$ & 0,010 & 8,42 & 1,10 & 0,396 \\
\hline \multicolumn{7}{|l|}{ Bekkur } \\
\hline 6. bekkur & 78,6 & $1475 / 1877$ & & 9,18 & 0,86 & \\
\hline 8. bekkur & 78,0 & $1710 / 2192$ & $<0,001$ & 8,35 & 1,04 & $<0,001$ \\
\hline 10. bekkur & 53,2 & $1073 / 2015$ & & 7,72 & 1,06 & \\
\hline \multicolumn{7}{|l|}{ Uppruni foreldra } \\
\hline Báđir af ísl. uppruna & 71,6 & $3545 / 4949$ & & 8,44 & 1,11 & \\
\hline Annað af erl. uppruna & 65,5 & $434 / 663$ & $<0,001$ & 8,27 & 1,24 & $<0,001$ \\
\hline Báđir af erl. uppruna & 57,3 & $223 / 389$ & & 7,98 & 1,38 & \\
\hline \multicolumn{7}{|l|}{ Fjölskyldugerð } \\
\hline Báðir kynforeldrar & 72,6 & $3175 / 4376$ & & 8,48 & 1,08 & \\
\hline Einstætt foreldri & 64,3 & $440 / 684$ & & 8,22 & 1,25 & \\
\hline Stjúpforeldri & 67,6 & $269 / 398$ & $<0,001$ & 8,11 & 1,25 & $<0,001$ \\
\hline Önnur fjölskyldugerð & 60,3 & $346 / 574$ & & 8,18 & 1,33 & \\
\hline \multicolumn{7}{|l|}{ Efnahagur fjölskyldu } \\
\hline Lakur (0-7 stig) & 68,5 & $651 / 951$ & & 8,38 & 1,22 & \\
\hline Miðlungs (8-10 stig) & 71,2 & $2534 / 3560$ & 0,061 & 8,42 & 1,13 & 0,195 \\
\hline Hár (11-13 stig) & 68,2 & $990 / 1451$ & & 8,35 & 1,14 & \\
\hline \multicolumn{7}{|l|}{ Búseta } \\
\hline Höfuðborgarsvæði & 71,0 & $2543 / 3580$ & & 8,43 & 1,13 & \\
\hline Landsbyggð & 68,5 & $1715 / 2504$ & $\mathbf{0 , 0 3 3}$ & 8,35 & 1,18 & 0,010 \\
\hline
\end{tabular}

1 p-gildi byggja á kí-kvaðrat prófi.

2 p-gildi byggja á t-prófi pegar hópar eru tveir, en F-prófi pegar hópar eru fleiri.

Dálkar til hægri í Töflu 1 sýna mun á meðaltölum svefnlengdar eftir einstökum hópum nemenda. Hópamunur er hliðstæður pví sem fram kom við samanburð á hlutfalli peirra sem náðu ráðlagðri svefnlengd. Ekki fannst pó marktækur munur á meðaltali svefnlengdar milli drengja og stúlkna. Nætursvefn var stystur meðal nemenda í 10. bekk (7,72 klst.) og hjá nemendum par sem báðir foreldrarnir voru af erlendum uppruna (7,98 klst.). 
Tafla 2. Aðhvarfsgreining á ráðlögðum svefni og svefnlengd eftir hópum íslenskra grunnskólanema.

\begin{tabular}{|c|c|c|c|c|c|c|}
\hline & \multicolumn{3}{|c|}{ Ráðlagður svefn ${ }^{1}$} & \multicolumn{3}{|c|}{ Svefnlengd (klst. $)^{2}$} \\
\hline & $\mathrm{b}$ & $\mathrm{OR}^{3}$ & $\mathrm{p}$ & $\mathrm{b}$ & beta $^{4}$ & $\mathrm{p}$ \\
\hline Fasti & 1,426 & & & 9,281 & & \\
\hline Kynferði (1=stúlka) & 0,162 & 1,176 & 0,007 & 0,042 & 0,018 & 0,098 \\
\hline $\begin{array}{l}\text { Bekkur } \\
\text { 6. bekkur5 } \\
\text { 8. bekkur } \\
\text { 10. bekkur }\end{array}$ & $\begin{array}{c}0 \\
-0,079 \\
-1,232\end{array}$ & $\begin{array}{c}1 \\
0,924 \\
0,292\end{array}$ & $\begin{array}{r}<0,001 \\
0,324 \\
<0,001\end{array}$ & $\begin{array}{c}0 \\
-0,830 \\
-1,459\end{array}$ & $\begin{array}{c}0 \\
-0,352 \\
-0,607\end{array}$ & $\begin{array}{l}<0,001 \\
<0,001 \\
<0,001\end{array}$ \\
\hline $\begin{array}{l}\text { Uppruni foreldra } \\
\text { Báðir af ísl. uppruna } 5 \\
\text { Annað af erl. uppruna } \\
\text { Báðir af erl. uppruna }\end{array}$ & $\begin{array}{c}0 \\
-0,327 \\
-0,500\end{array}$ & $\begin{array}{c}1 \\
0,721 \\
0,607\end{array}$ & $\begin{array}{l}<0,001 \\
<0,001 \\
<0,001\end{array}$ & $\begin{array}{c}0 \\
-0,180 \\
-0,325\end{array}$ & $\begin{array}{c}0 \\
-0,050 \\
-0,069\end{array}$ & $\begin{array}{l}<0,001 \\
<0,001 \\
<0,001\end{array}$ \\
\hline $\begin{array}{l}\text { Fjölskyldugerð } \\
\text { Báðir kynforeldrar } \\
\text { Einstæutt foreldri } \\
\text { Stjúpforeldri } \\
\text { Önnur fjölskyldugerð }\end{array}$ & $\begin{array}{c}0 \\
-0,308 \\
-0,064 \\
-0,559\end{array}$ & $\begin{array}{c}1 \\
0,735 \\
0,938 \\
0,572\end{array}$ & $\begin{array}{r}<0,001 \\
0,001 \\
0,599 \\
<0,001\end{array}$ & $\begin{array}{c}0 \\
-0,211 \\
-0,167 \\
-0,290\end{array}$ & $\begin{array}{c}0 \\
-0,059 \\
-0,036 \\
-0,075\end{array}$ & $\begin{array}{r}<0,001 \\
<0,001 \\
0,001 \\
<0,001\end{array}$ \\
\hline $\begin{array}{l}\text { Efnahagur fjölskyldu } \\
\text { Lakur (0-7 stig) } \\
\text { Miðlungs (8-10 stig) } \\
\text { Hár (11-13 stig) })^{5}\end{array}$ & $\begin{array}{c}-0,023 \\
-0,231 \\
0\end{array}$ & $\begin{array}{c}0,977 \\
0,794 \\
1\end{array}$ & $\begin{array}{l}0,011 \\
0,793 \\
0,022\end{array}$ & $\begin{array}{c}-0,029 \\
-0,106 \\
0\end{array}$ & $\begin{array}{c}-0,013 \\
-0,040 \\
0\end{array}$ & $\begin{array}{l}0,030 \\
0,425 \\
0,012\end{array}$ \\
\hline $\begin{array}{l}\text { Búseta } \\
\quad(1=\text { Höfuðborgarsvæði) } \\
\text { Nagelkerke } \mathrm{R}^{2} \\
\mathrm{R}^{2}\end{array}$ & 0,113 & $\begin{array}{l}1,120 \\
0,111\end{array}$ & 0,068 & 0,058 & 0,025 & 0,027 \\
\hline
\end{tabular}

1 Lógistísk aðhvarfsgreining (e. logistic regression)

2 Venjuleg aðhvarfsgreining (e. ordinary least squares)

3 Líkindahlutfall (e. odds ratio)

4 Staðlaður aðhvarfsstuðull

5 Samanburðarhópur í aðhvarfsgreiningu

Tafla 2 sýnir niðurstöður margbátta aðhvarfsgreiningar á ráðlögðum svefni og svefnlengd. Munur er áfram til staðar á ráðlögðum svefni kynjanna pegar tekið er tillit til annara bakgrunnspátta, en ekki er marktækur munur á meðalsvefnlengd kynjanna. Jafnframt er munur milli bekkjardeilda á ráðlögðum svefni og svefnlengd og par skera 10. bekkingar sig úr. Munur er á ráðlögðum svefni og svefnlengd eftir uppruna foreldra og par hallar enn á nemendur sem eiga foreldra af erlendum uppruna. Nemendur sem búa með báðum kynforeldrum hafa hagstæðari svefnvenjur en nemendur í öðrum fjölskyldugerðum, bæði að pví er varðar ráðlagðan svefn og svefnlengd. Niðurstöður aðhvarfsgreiningarinnar sýna nokkurn mun á svefnvenjum eftir efnahag fjölskyldu, en par hallaði á nemendur sem bjuggu í fjölskyldum með miðlungs efnahag. Samkvæmt aðhvarfsgreiningunni sváfu landsbyggðarnemendur að jafnaði skemur en nemendur á höfuðborgarsvæðinu, en pó reyndist ekki marktækur munur á ráðlögðum svefni eftir búsetu nemendanna. 
Rannsóknin leiddi í ljós að mismunandi svefnlengd nemendanna á skóladögum réðst af háttatíma $(\mathrm{r}=-0,90 ; \mathrm{t}=161,02 ; \mathrm{p}<0,001)$ miklu fremur en fótaferðartíma $(\mathrm{r}=0,26 ; \mathrm{t}=21,00 ; \mathrm{p}<0,001)$. Mynd 1 sýnir hlutfallslega skiptingu háttatíma nemendanna eftir bekkjardeild. Algengustu háttatímarnir voru kl. 21:30 og kl. 22:00 í 6. bekk (um 30\% nemenda með hvorn háttatímann). Algengasti háttatíminn í 8. bekk var 22:30 (26\% nemenda) og næstalgengasti kl. 22:00 (21\% nemenda). Algengasti háttatími í 10. bekk var kl. 23:00 (19\% nemenda), en næstalgengasti á miðnætti (17\% nemenda). Myndin sýnir að mest dreifing var á háttatíma í 10. bekk en peir nemendur fóru almennt mun seinna að sofa en nemendur í yngri bekkjardeildum. Pannig fóru 23\% nemenda í 10. bekk í háttinn eftir miðnætti.

\section{5}

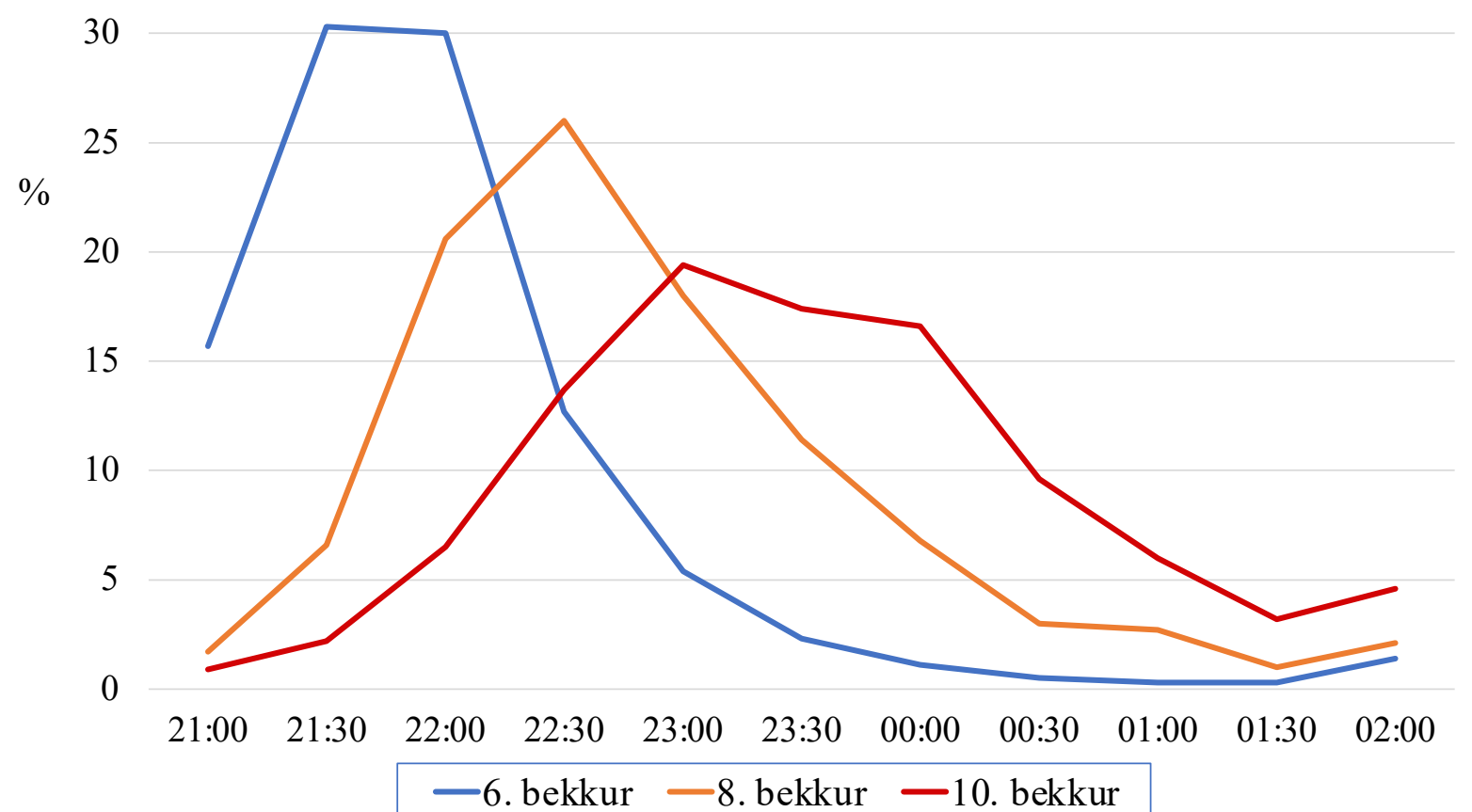

Mynd 1. Hlutfallsleg skipting á háttatíma nemenda eftir bekkjardeild.

\section{Umræður}

\section{Svefnlengd og háttatími}

Umtalsverður hluti íslenskra ungmenna nær ekki nægum nætursvefni miðað við alpjóðlegar svefnráðleggingar og ræðst pað helst af pví hve mörg peirra fara seint í háttinn. Útbreiðsla takmarkaðs svefns út frá alpjóðlegum ráðleggingum er misjöfn eftir hópum ungmenna og par hallar helst á nemendur úr 10. bekk, nemendur af erlendum uppruna, nemendur sem búa ekki með báðum lífforeldrum eða búa á landsbyggðinni.

Um 70\% ungmenna í 6., 8. og 10. bekk ná ráðlögðum nætursvefni, en færri 10. bekkingar ná viðmiðunum um svefnlengd á skóladögum en nemendur í 6. og 8. bekk. Pessar niðurstöður eru í takt við fyrri rannsóknaniðurstöður par sem háttatími og svefnlengd meðal ungmenna breyttist með hækkandi aldri (Gustafsson o.fl., 2019; Olds o.fl., 2010) en lítill munur er milli kynja (Olds o.fl., 2010; Ortega o.fl., 2010). Háttatími virðist hafa hvað mest áhrif á stuttan svefn ungmennanna, en seinkun á dægursveiflu (Gruber o.fl., 2014; Phillips, 2009; Wright o.fl., 2012) með tilheyrandi seinkun á háttatíma og skóla snemma morguns eru pekktir pættir sem hafa áhrif á svefnlengd ungmenna (Rognvaldsdottir o.fl., 2017; Wheaton o.fl., 2015). Ípróttaæfingar á kvöldin og aukið sjón- 
varpsáhorf tengjast hækkandi aldri ungmenna og geta skýrt að hluta til styttri svefnlengd eldri ungmennanna (Ortega o.fl., 2010). Skjátími ungmenna snýr pó ekki einungis að sjónvarpi, par sem aðgengi að skemmtiefni hvers konar allan sólarhringinn er einnig tengt styttri svefnlengd ungmenna (Garmy o.fl., 2020; Garmy og Ward, 2018; Hale og Guan, 2015; Hrafnkelsdottir o.fl., 2020). Pá benda rannsóknir til að koffínneysla unglinga á Vesturlöndum hafi aukist á síðari árum sem getur tengst seinkun svefns og styttri svefntíma (Bonnar og Gradisar, 2015). Tengsl hreyfingar og svefns eru nokkuð flókin en hreyfing er í grunninn talin hafa jákvæð áhrif á bæði svefnlengd og svefngæði (Lang o.fl., 2015). Kröftug hreyfing að kvöldi til getur pó seinkað háttatíma en samt haft góð áhrif á svefngæði (Stutz o.fl., 2019). Íslendingar hafa löngum verið pekktir fyrir að fara seint í háttinn og sofa skemur yfir nóttina en gengur og gerist meðal nágrannalanda (Brychta o.fl., 2016; Helgi Kristbjarnarson o.fl., 1985; Thorleifsdottir o.fl., 2002). Í nýrri HBSC-samanburðarrannsókn meðal pjóða Evrópu og Norður-Ameríku virðast svefnvenjur íslenskra ungmenna pó ekki skera sig sérstaklega úr (Gariepy o.fl., 2020). Mismunandi háttatími barna og foreldra og svefnlengd meðal ungmenna milli landa hefur m.a. verið skýrð með mismunandi tímasetningu á upphafi skólatíma að morgni (Short o.fl., 2013; Wheaton o.fl., 2015). Menningarmunur hvers konar á t.d. háttatímum og matartímum barna og foreldra hefur einnig verið tengdur við veðurfar og hitastig (Smith o.fl., 2002). Pá hafa tengsl milli háttatíma ungmenna og landfræðilegrar staðsetningar pjóða frá miðbaugi einnig verið skoðuð, en dagar með styttri dagsbirtu spá fyrir um seinkun á háttatíma (Bartel o.fl., 2017). Ljóst er að svefnvenjur barna eru mótaðar af fjölpættu samspili menningar samfélagsins og líffræðilegra parfa einstaklingsins (Jenni og O’Connor, 2005).

\section{Félags- og lýðfræðileg staða ungmenna}

Pegar svefn ungmenna í rannsókninni var borinn saman milli hópa af ólíkum pjóðernisuppruna, fjölskyldugerð og búsetu kom í ljós að allir pessir pættir höfðu tengsl við nætursvefn. Hins vegar var lítill munur á svefnlengd eftir efnahagslegri stöðu fjölskyldu. Pegar alpjóðlegu HBSC-gögnin eru borin saman milli landa kemur í ljós að svefnlengd er breytileg milli pjóða og pjóðfélagshópa og lakari svefn finnst meðal ungmenna í fjölskyldum með lakari efnahagslega stöðu (Gariepy o.fl., 2020). Fyrri rannsóknir hafa einnig bent til pess að efnahagsleg staða fjölskyldu hafi neikvæð áhrif á svefnlengd ungmenna (Felden o.fl., 2015; Philbrook o.fl., 2020). Pví er ástæða til að skoða nánar efnahagslega stöðu íslenskra fjölskyldna og möguleg áhrif efnahagslegrar stöðu á svefnlengd og svefngæði barna. Pá kom einnig fram munur á svefni milli kynjanna en piltar náðu síður rádlagðri svefnlengd en stúlkur, sem er í samræmi við niðurstöður fleiri rannsókna (Jarrin o.fl., 2014). Prátt fyrir pað var ekki marktækur munur á svefnlengd kynjanna. Í nýlegri rannsókn á ungmennum í 10. bekk, par sem svefn var mældur með hreyfimælum, fannst enginn kynjamunur á svefnlengd, en aftur á móti fóru drengir marktækt seinna í háttinn og á fætur (Rognvaldsdottir o.fl., 2017).

Í pessari rannsókn mælast nemendur sem búa á landsbyggðinni með marktækt styttri nætursvefn en nemendur á höfuðborgarsvæðinu, sem samræmist eldri íslenskri rannsókn á svefnlengd eftir búsetu meðal 15 ára ungmenna (Thorleifsdottir o.fl., 2002). Pessi munur er pó lítill og varast ber að draga afgerandi ályktanir af honum. Erlendar rannsóknir á svefnlengd barna og ungmenna eftir búsetu eru misvísandi og benda annaðhvort til pess að ungmenni í borg sofi skemur yfir nóttina (Kim o.fl., 2020), eða að enginn munur sé á svefnlengd eftir búsetu (Galy o.fl., 2020). Dví má ætla að samanburður milli landssvæða geti verið háður ýmsum samfélagslegum páttum öðrum en búsetu einni og sér.

Ungmenni sem bjuggu með báðum lífforeldrum sínum náðu frekar ráðlögðum nætursvefni en pau sem bjuggu í annarri fjölskyldugerð. Lítið er til af rannsóknum sem skoða samspil milli fjölskyldugerðar og svefnlengdar meðal ungmenna. Fjölskyldugerðir aðrar en sú að búa með báðum lífforeldrum geta einnig verið með ýmsum hætti. Í rannsókn á ungmennum í menntaskóla í Bandaríkjunum má sjá að ungmenni sem búa hjá öðru foreldrinu mælast með lakari svefngæði og styttri nætursvefn en pau sem búa hjá tveimur foreldrum (lífforeldrum eða í stjúpfjölskyldu) (Troxel o.fl., 2014). Evrópsk rannsókn á fjölskyldugerðum barna fann pó ekki mælanlegan mun á svefnlengd og háttatíma barna 
eftir fjölskyldugerð, prátt fyrir mun á skjátímanotkun (Stahlmann o.fl., 2020). Rannsóknir hérlendis sýna að stuðningur og aðhald foreldra er með misjöfnum hætti milli fjölskyldugerða (Rúnar Vilhjálmsson, 2011). Mögulegt er að ýmsir pættir í samskiptum foreldra og barna skýri að einhverju leyti mun á svefnlengd og reglu á svefntíma ungmenna milli fjölskyldugerða. Niðurstöðurnar sýndu skýran mun á svefnlengd eftir pjóðernisuppruna. Pjóðernisuppruni er flókið fyrirbæri en rannsóknir hafa greint mun á svefni eftir bæði kynpætti og pjóðerni (Guglielmo o.fl., 2018; Marczyk Organek o.fl., 2015; Rao o.fl., 2009). Varasamt er pó að draga ályktanir af peim niðurstöðum fyrr en búið er að greina frekar félagslega stöðu pessara hópa og líffræðilegan breytileika og pví pörf á frekari rannsóknum.

\section{Styrkleikar og takmarkanir}

Rannsóknin „Heilsa og lífskjör skólanema“ er íslenskur hluti alpjóðlegs HBSC-rannsóknarverkefnis, en íslenski spurningalistinn innihélt viðbótarspurningar um svefn árið 2018. Spurningalistar hafa verið notaðir í svefnrannsóknum til að meta svefnlengd út frá eigin mati svarenda (Lang o.fl., 2015). Vísbendingar eru um að slíkt mat ofmeti svefnlengd pegar pað er borið saman við hlutlægar svefnmælingar. Pað bendir til pess að ungmenni fái jafnvel enn styttri nætursvefn en pau greina frá (Arora o.fl., 2013). Í íslenskri rannsókn á 15-16 ára ungmennum var háttatími metinn með bæði spurningalistum og með hreyfimælum. Par kom fram ákveðið samræmi í mælingum á háttatímanum, en hreyfimælirinn mældi háttatímann pó um pað bil klukkustund seinna en spurningalistinn (Brychta o.fl., 2019). Báðar mæliaðferðirnar hafa sína kosti og galla en gögnum úr spurningalistum er auðveldara að safna og peim fylgir minni tækjakostnaður og minni pörf á tæknikunnáttu hvað mælitækið varðar (Galland o.fl., 2018; Lewandowski o.fl., 2011). Prátt fyrir að spurningalistar hafi verið taldir valda mæliskekkju á svefnlengd hafa peir samt sem áður verið taldir gagnlegir til samanburðar milli landa og hópa í stórum rannsóknum á landsvísu (Arora o.fl., 2013; Biddle o.fl., 2015; Guedes o.fl., 2016; Wolfson o.fl., 2003). Benda má á að hin alpjóðlegu viðmið (Hirshkowitz o.fl., 2015) eru einnig byggð á spurningalistum og pví eðlilegt að styðjast við sambærilegt mat. Landskannanir eins og í HBSC-rannsóknarverkefninu byggja á stórum úrtökum, eru næmar á mun á milli hópa og gefa góða mynd af útbreiðslu viðfangsefna eins og svefns barna og ungmenna. Par eð styrkur tölfræðilegra prófa í pessum könnunum er mjög hár ber að hafa í huga að einungis lítill munur milli hópa getur reynst marktækur.

\section{Ályktun}

Mikilvægt er að gefa nánari gaum að nætursvefni íslenskra ungmenna, einkum meðal eldri ungmenna og í peim hópum par sem félagsleg staða er lakari. Pá ber einnig að hafa í huga að aðrir pættir en svefnlengd hafa með góðar svefnvenjur að gera, svo sem svefngæði og reglulegur hátta- og fótaferðartími. Í frekari rannsóknum á svefni barna og ungmenna parf að skoða frekar ýmsa pætti sem tengjast svefni eins og hreyfingu, koffínneyslu og skjátíma. Pá má einnig nefna veðurfar og líkamsklukku. Svefnvenjur ungmenna eru samfélagslegt verkefni peirra er koma að lýðheilsu barna og unglinga og parfnast nánari skoðunar og úrlausna.

\section{Pakkir}

Við pökkum öllum peim nemendum sem deildu upplýsingum um sig og líðan sína í HBSC-könnuninni, sem og kennurum og starfsmönnum sem lögðu sitt af mörkum við fyrirlögnina. Loks færum við stjórnanda könnunarinnar, Ársæli Arnarssyni, sérstakar pakkir. 


\section{Sleep duration amongst Icelandic school children}

Sleep health is important for general well-being and should be prioritized in connection with proper nutrition and regular physical activity for overall quality of life for all ages. In recent decades, studies on adequate nightly sleep duration have found that sleep is important for health, cognitive function and development of young people. Despite increasing amount of sleep studies in recent years, much is still unknown about the prevalence of sleep and sleep habits among young people. Socioeconomic status, family structure, and residential area of the family are among factors that could provide an understanding of different sleep patterns of school children. The aim of the study was to investigate whether sleep duration in Icelandic school children is in accordance with international sleep recommendations, examine the average sleep duration of the students, and assess differences in recommended sleep and sleep duration between different social groups.

The study is based on the national survey of "Health Behavior in School-aged Children“ (HBSC) and was conducted among students in 6th, 8th and 10th grade in 2018. The survey is an international research collaboration which collects data every four years on health and well-being, health-related behavior and social environment of schoolchildren in Europe and North America. Country specific questions are added to the HBSC standardized questionnaire and detailed sleep questions for Icelandic schoolchildren were included in the questionnaire in 2018. A total of 7,159 students participated in the Icelandic HBSC survey in 2018. Among other things, students were asked about their usual bedtime and wake-up times. Criteria for adequate sleep duration were based on international recommendations for young people which are 9-11 hours per night in 6th grade, and 8-10 hours per night for students in 8 th and 10th grade.

Overall, about $30 \%$ of the children did not meet the recommended sleep duration criteria on weekdays. Boys slept fewer hours than girls, and fewer boys reached the recommended sleep duration. 10th graders slept fewer hours than students in the lower grades and were less likely to get recommended hours of sleep. Students with parents of foreign origin slept fewer hours and achieved recommended sleep less often than other students. Students who lived with both biological parents slept longer and received recommended sleep more often than students in other family types. Students living in urban areas slept longer and achieved recommended sleep more often than students living in rural areas. Some differences in sleeping patterns were also observed by family economic status. The students' sleep duration on school days had a much higher correlation to their reported bedtimes $(r=-0.90 ; \mathrm{p}<0.001)$ than their reported wake-up times $(\mathrm{r}=0.26 ; \mathrm{p}<0.001)$. The most frequent bedtimes for students in 6th grade were at 21:30 and 22:00 (about 30\% of the students reported each bedtime). The most frequent bedtime for 8 th grade students was at $22: 30$ and $22: 00(26 \%$ and $21 \%$ of the students reported those bedtimes respectively). The most frequent bedtime for students in 10th grade was at 23:00 and midnight (reported by $19 \%$ and $17 \%$ of the students respectively).

A significant proportion of Icelandic schoolchildren did not receive the recommended hours of sleep during the night. It is important to pay closer attention to the overnight sleep of Icelandic school children, especially in those groups where bedtime and sleep duration is most problematic. Sleep characteristics, such as timing of the sleep period and sleep quality are also important factors in sleep hygiene. Behavioral factors known to foster sleep health include regular physical activity and limited screen time. Prioritizing sleep health of school children should be based on cooperation between the school, sports clubs, parents, and public health professionals.

Key words: Sleep, sleep duration, bedtime, adolescents, family structure 


\section{Um höfunda}

Guðrún Kristjánsdóttir (gkrist@hi.is) er prófessor í hjúkrunarfræði við Hjúkrunarfræðideild Háskóla Íslands og forstöðumaður fræðasviðs barnahjúkrunar við Hjúkrunarfræðideild og við Landspítala. Hún lauk BS-prófi í hjúkrunarfræði frá Háskóla Îslands árið 1983, meistaraprófi og sérhæfingu í barna- og fjölskylduhjúkrun frá Boston University og Children’s Hospital í Boston árið 1986 og doktorsprófi við Norræna heilbrigðisháskólann í Gautaborg árið 1996. Rannsóknir hennar hafa m.a. beinst að líðan og högum skólabarna með áherslu á hreyfingu, áhættuhegðun, verki, einelti og svefn, auk annarra pátta sem tengjast heilsu og vellíðan.

Rúnar Vilhjálmsson (runarv@hi.is) er prófessor í félagsfræði við Hjúkrunarfræðideild Háskóla Íslands og er jafnframt gestaprófessor við heilbrigðisvísindadeild Háskólans í Lundi, Svípjóð. Hann lauk BA-prófi í félagsfræði frá Háskóla Íslands árið 1982, meistaraprófi í félagsfræði frá Wisconsinháskóla í Madison árið 1984 og doktorsprófi î félagsfræði frá sama skóla árið 1993. Rannsóknir hans hafa meðal annars beinst að hollustu- og áhættuhegðun ungmenna, félagslegum stuðningi ungmenna og fullorðinna, geðheilsu fullorðinna og heilbrigðispjónustunotkun og aðgengi að heilbrigðispjónustu.

Vaka Rögnvaldsdóttir (vakar@hi.is) er lektor í íprótta- og heilsufræði við Menntavísindasvið Háskóla Î́lands. Hún lauk ípróttakennaraprófi frá Kennaraháskóla Íslands árið 1999, B.Sc.-gráðu í hagfræði frá Auburn University Montgomery árið 2002, M.Sc.-gráðu árið 2011 og PhD-gráðu árið 2020 í íprótta- og heilsufræði frá Háskóla Íslands. Síðastliðin ár hafa rannsóknir hennar aðallega beinst að svefni, hreyfingu og heilsu ungmenna.

\section{About the authors}

Guðrún Kristjánsdóttir (gkrist@hi.is) is Professor of Nursing at the University of Iceland Faculty of Nursing, and Chair of Research and Development of Children and their Families at the Landspitali - University Hospital in Reykjavik. She received her BSc degree (1986) in Children's nursing from Boston University, and clinical specialist training from the Children's Hospital in Boston. She completed her PhD in 1996 from the Nordic School of Public Health. Her subsequent research has, along with other areas, focused on the health and wellbeing of school-children with emphasis on mobility, risk behaviour, pain, bullying, and sleep.

Rúnar Vilhjálmsson (runarv@hi.is) is Professor of Sociology at the University of Iceland Faculty of Nursing, and Guest Professor in the Department of Health Sciences at the University of Lund, Sweden. He completed his B.A. degree in sociology from the University of Iceland in 1982, an M.Sc. degree in sociology from the University of Wisconsin-Madison in 1984, and a PhD degree in sociology from UW-Madison in 1993. His research focuses on positive and negative health-related behavior in adolescents, social support in adolescence and adulthood, adult mental health, the use of health services and access to health care.

Vaka Rögnvaldsdóttir (vakar@hi.is) is an Associate Professor in Sport and Health Science at University of Iceland, School of Education. She completed her physical education teacher's degree from the Iceland College of Education in 1999, a B.Sc. degree in economics from Auburn University Montgomery in 2002, an M.Sc. degree in 2011 and a PhD degree in 2020 from the Faculty of Health Promotion, Sport and Leisure Studies at the University of Iceland. Recently, her research has focused on sleep, physical activity and health of adolescents. 


\section{Heimildir}

Adler, N. E., Boyce, T., Chesney, M. A., Cohen, S., Folkman, S., Kahn, R. L. og Syme, S. L. (1994). Socioeconomic status and health. The challenge of the gradient. American Psychologist, 49(1), 15-24. https://doi. org/10.1037//0003-066x.49.1.15

Arora, T., Broglia, E., Pushpakumar, D., Lodhi, T. og Taheri, S. (2013). An investigation into the strength of the association and agreement levels between subjective and objective sleep duration in adolescents. PLoS One, 8(8), e72406. https://doi.org/10.1371/journal.pone.0072406

Ársæll Arnarsson. (2019). Depurð meðal skólabarna á Íslandi. Sérrit Netlu 2019-Alpjóðlegar menntakannanir. https://doi.org/10.24270/serritnetla.2019.30

Bartel, K., van Maanen, A., Cassoff, J., Friborg, O., Meijer, A. M., Oort, F., Williamson, P., Gruber, R., Knäuper, B. og Gradisar, M. (2017). The short and long of adolescent sleep: The unique impact of day length. Sleep Medicine, 38, 31-36. https://doi.org/10.1016/j.sleep.2017.06.018

Beebe, D. W., Simon, S., Summer, S., Hemmer, S., Strotman, D. og Dolan, L. M. (2013). Dietary intake following experimentally restricted sleep in adolescents. Sleep, 36(6), 827-834. https://doi.org/10.5665/ sleep. 2704

Biddle, D. J., Robillard, R., Hermens, D. F., Hickie, I. B. og Glozier, N. (2015). Accuracy of self-reported sleep parameters compared with actigraphy in young people with mental ill-health. Sleep Health, 1(3), 214-220. https://doi.org/10.1016/j.sleh.2015.07.006

Bonnar, D. og Gradisar, M. (2015). Caffeine and sleep in adolescents: A systematic review. Journal of Caffeine Research, 5(3), 105-114. https://doi.org/10.1089/jcr.2014.0036

Brychta, R. J., Arnardottir, N. Y., Johannsson, E., Wright, E. C., Eiriksdottir, G., Gudnason, V., Marinac, C. R., Davis, M., Koster, A., Caserotti, P., Sveinsson, P., Harris, T. og Chen, K. Y. (2016). Influence of day length and physical activity on sleep patterns in older Icelandic men and women. Journal of Clinical Sleep Medicine, 12(2), 203-213. https://doi.org/10.5664/jcsm.5486

Brychta, R. J., Rögnvaldsdóttir, V., Guðmundsdóttir, S. L., Stefánsdóttir, R., Hrafnkelsdóttir, S. M., Gestsdóttir, S., Arngrímsson, S. A., Chen, K. Y. og Jóhannsson, E. (2019). Longitudinal change in adolescent bedtimes measured by self-report and actigraphy. Journal for the Measurement of Physical Behavior, 2(4), 282-287. https://doi.org/10.1123/jmpb.2019-0021

Chapman, C. D., Benedict, C., Brooks, S. J. og Schioth, H. B. (2012). Lifestyle determinants of the drive to eat: A meta-analysis. The American Journal of Clinical Nutrition, 96(3), 492-497. https://doi.org/10.3945/ ajcn. 112.039750

Chaput, J. P. (2014). Sleep patterns, diet quality and energy balance. Physiology \& Behavior, 134, 86-91. https:// doi.org/10.1016/j.physbeh.2013.09.006

Chaput, J. P., Dutil, C. og Sampasa-Kanyinga, H. (2018). Sleeping hours: What is the ideal number and how does age impact this? Nature and Science of Sleep, 10, 421-430. https://doi.org/10.2147/NSS.S163071

Chaput, J. P. og St-Onge, M. P. (2014). Increased food intake by insufficient sleep in humans: Are we jumping the gun on the hormonal explanation? Frontiers in Endocrinology, 5, 116. https://doi.org/10.3389/ fendo.2014.00116

Conklin, A. I., Yao, C. A. og Richardson, C. G. (2018). Chronic sleep deprivation and gender-specific risk of depression in adolescents: A prospective population-based study. BMC Public Health, 18(1), 724. https:// doi.org/10.1186/s12889-018-5656-6

Dahl, R. E. (1996). The impact of inadequate sleep on children's daytime cognitive function. Seminars in Pediatric Neurology, 3(1), 44-50. https://doi.org/10.1016/s1071-9091(96)80028-3

Eaton, D. K., Kann, L., Kinchen, S., Shanklin, S., Ross, J., Hawkins, J., Harris, W. A., Lowry, R., McManus, T., Chyen, D., Lim, C., Whittle, L., Brener, N. D. og Wechsler, H. (2010). Youth risk behavior surveillance - United States, 2009. MMWR Surveillance Summaries, 59(5), 1-142. https:/www.ncbi.nlm.nih. gov/pubmed/20520591

Einar B. Porsteinsson og Ársæll Arnarsson. (2018). Heilsa og lífskjör skólanema á Íslandi (HBSC). Rannsóknarstofa i tómstundafreðum við Háskóla Islands. https://www.stjornarradid.is/library/01--Frettatengt---myndir-og skrar/MRN/HBSC_Skýrsla\%202018_Landssvæði.pdf

Felden, É. P. G., Leite, C. R., Rebelatto, C. F., Andrade, R. D. og Beltrame, T. S. (2015). [Sleep in adolescents of different socioeconomic status: A systematic review]. Revista Paulista de Pediatria, 33(4), 467-473. https:// doi.org/10.1016/j.rpped.2015.01.011 
Galland, B. C., Short, M. A., Terrill, P., Rigney, G., Haszard, J. J., Coussens, S., Foster-Owens, M. og Biggs, S. N. (2018). Establishing normal values for pediatric nighttime sleep measured by actigraphy: A systematic review and meta-analysis. Sleep, 41(4), zsy017. https://doi.org/10.1093/sleep/zsy017

Galy, O., Paufique, E., Nedjar-Guerre, A., Wacalie, F., Wattelez, G., Le Roux, P. Y., Ponidja, S., Zongo, P., Serra-Mallol, C., Allman-Farinelli, M. og Frayon, S. (2020). Living in rural and urban areas of New Caledonia: Impact on food consumption, sleep duration and anthropometric parameters among Melanesian adolescents. Nutrients, 12(7), 2047. https://doi.org/10.3390/nu12072047

Gangwisch, J. E., Malaspina, D., Babiss, L. A., Opler, M. G., Posner, K., Shen, S., Blake Turner, J., Zammit, G. K. og Ginsberg, H. N. (2010). Short sleep duration as a risk factor for hypercholesterolemia: Analyses of the National longitudinal study of adolescent health. Sleep, 33(7), 956-961. https://doi.org/10.1093/ sleep/33.7.956

Gariepy, G., Danna, S., Gobina, I., Rasmussen, M., Gaspar de Matos, M., Tynjälä, J., Janssen, I., Kalman, M., Villeruša, A., Husarova, D., Brooks, F., Elgar, F. J., Klavina-Makrecka, S., Šmigelskas, K., Gaspar, T. og Schnohr, C. (2020). How are adolescents sleeping? Adolescent sleep patterns and sociodemographic differences in 24 European and North American countries. Journal of Adolescent Health, 66(suppl. 6), S81-S88. https://doi.org/10.1016/j.jadohealth.2020.03.013

Garmy, P., Idecrans, T., Hertz, M., Sollerhed, A. C. og Hagell, P. (2020). Is sleep duration associated with self-reported overall health, screen time, and nighttime texting among adolescents? Journal of International Medical Research, 48(3), 300060519892399. https://doi.org/10.1177/0300060519892399

Garmy, P. og Ward, T. M. (2018). Sleep habits and nighttime texting among adolescents. The Journal of School Nursing, 34(2), 121-127. https://doi.org/10.1177/1059840517704964

Gradisar, M., Gardner, G. og Dohnt, H. (2011). Recent worldwide sleep patterns and problems during adolescence: A review and meta-analysis of age, region, and sleep. Sleep Medicine, 12(2), 110-118. https://doi. org/10.1016/j.sleep.2010.11.008

Gruber, R., Carrey, N., Weiss, S. K., Frappier, J. Y., Rourke, L., Brouillette, R. T. og Wise, M. S. (2014). Position statement on pediatric sleep for psychiatrists. Journal of the Canadian Academy of Child and Adolescent Psychiatry, 23(3), 174-195. https://www.ncbi.nlm.nih.gov/pubmed/25320611

Guedes, L. G., Abreu Gde, A., Rodrigues, D. F., Teixeira, L. R., Luiz, R. R. og Bloch, K. V. (2016). [Comparison between self-reported sleep duration and actigraphy among adolescents: Gender differences]. Revista Brasileira Epidemiologia, 19(2), 339-347. https://doi.org/10.1590/1980-5497201600020011

Guglielmo, D., Gazmararian, J. A., Chung, J., Rogers, A. E. og Hale, L. (2018). Racial/ethnic sleep disparities in US school-aged children and adolescents: A review of the literature. Sleep Health, 4(1), 68-80. https:// doi.org/10.1016/j.sleh.2017.09.005

Gustafsson, M. L., Laaksonen, C., Salanterä, S., Löyttyniemi, E. og Aromaa, M. (2019). Changes in the amount of sleep and daytime sleepiness: A follow-up study of schoolchildren from ages 10 to 15 years. International Journal of Nursing Practice, 25(1), e12689. https://doi.org/10.1111/ijn.12689

Hale, L. og Guan, S. (2015). Screen time and sleep among school-aged children and adolescents: A systematic literature review. Sleep Medicine Reviews, 21, 50-58. https://doi.org/10.1016/j.smrv.2014.07.007

Helgi Kristbjarnarson, Hallgrímur Magnússon, Guðmundur I. Sverrisson, Eiríkur Örn Arnarson og Tómas Helgason. (1985). Könnun á svefnvenjum Íslendinga. Laknablaðið, 71(6), 193-198. http://timarit.is/view_ page_init.jsp?pageId $=5892850$

Hirshkowitz, M., Whiton, K., Albert, S. M., Alessi, C., Bruni, O., DonCarlos, L., Hazen, N., Herman, J., Adams Hillard, P. J., Katz, E. S., Kheirandish-Gozal, L., Neubauer, D. N., O'Donnell, A. E., Ohayon, M., Peever, J., Rawding, R., Sachdeva, R. C., Setters, B., Vitiello, M. V. og Ware, J. C. (2015). National sleep foundation's updated sleep duration recommendations: Final report. Sleep Health, 1(4), 233-243. https:// doi.org/10.1016/j.sleh.2015.10.004

Hrafnkelsdottir, S. M., Brychta, R. J., Rognvaldsdottir, V., Chen, K. Y., Johannsson, E., Gudmundsdottir, S. L. og Arngrimsson, S. A. (2020). Less screen time and more physical activity is associated with more stable sleep patterns among Icelandic adolescents. Sleep Health, 6(5), 609-617. https://doi.org/10.1016/j. sleh.2020.02.005

Jarrin, D. C., McGrath, J. J. og Quon, E. C. (2014). Objective and subjective socioeconomic gradients exist for sleep in children and adolescents. Health Psychology, 33(3), 301-305. https://doi.org/10.1037/a0032924

Jenni, O. G. og O'Connor, B. B. (2005). Children's sleep: An interplay between culture and biology. Pediatrics, 115(suppl. 1), 204-216. https://doi.org/10.1542/peds.2004-0815B 
Kelly, Y., Kelly, J. og Sacker, A. (2013). Time for bed: Associations with cognitive performance in 7-year-old children: A longitudinal population-based study. Journal of Epidemiology \& Community Health, 67(11), 926-931. https://doi.org/10.1136/jech-2012-202024

Keyes, K. M., Maslowsky, J., Hamilton, A. og Schulenberg, J. (2015). The great sleep recession: Changes in sleep duration among US adolescents, 1991-2012. Pediatrics, 135(3), 460-468. https://doi.org/10.1542/ peds.2014-2707

Kim, J., Noh, J. W., Kim, A. og Kwon, Y. D. (2020). Demographic and socioeconomic influences on sleep patterns among adolescent students. International Journal of Environmental Research and Public Health, 17(12), 4378. https://doi.org/10.3390/ijerph17124378

Lang, C., Kalak, N., Brand, S., Holsboer-Trachsler, E., Puhse, U. og Gerber, M. (2015). The relationship between physical activity and sleep from mid adolescence to early adulthood. A systematic review of methodological approaches and meta-analysis. Sleep Medicine Reviews, 28, 32-45. https://doi.org/10.1016/j.smrv.2015.07.004

Lewandowski, A. S., Toliver-Sokol, M. og Palermo, T. M. (2011). Evidence-based review of subjective pediatric sleep measures. Journal of Pediatric Psychology, 36(7), 780-793. https://doi.org/10.1093/jpepsy/jsq119

Marczyk Organek, K. D., Taylor, D. J., Petrie, T., Martin, S., Greenleaf, C., Dietch, J. R. og Ruiz, J. M. (2015). Adolescent sleep disparities: Sex and racial/ethnic differences. Sleep Health, 1(1), 36-39. https:// doi.org/10.1016/j.sleh.2014.12.003

Matricciani, L., Olds, T. og Petkov, J. (2012). In search of lost sleep: Secular trends in the sleep time of school-aged children and adolescents. Sleep Medicine Reviews, 16(3), 203-211. https://doi.org/10.1016/j. smrv.2011.03.005

Megdal, S. og Schernhammer, E. S. (2007). Correlates for poor sleepers in a Los Angeles high school. Sleep medicine, 9(1), 60-63. https://doi.org/10.1016/j.sleep.2007.01.012

Mignot, E. (2008). Why we sleep: The temporal organization of recovery. PLoS Biology, 6(4), e106. https:// doi.org/10.1371/journal.pbio.0060106

National Sleep Foundation. (2006). 2006 Sleep in America Poll: America's sleepy teens. http://sleepfoundation. $\mathrm{org} /$ sites/default/files/2006_summary_of_findings.pdf

Olds, T., Blunden, S., Petkov, J. og Forchino, F. (2010). The relationships between sex, age, geography and time in bed in adolescents: A meta-analysis of data from 23 countries. Sleep Medicine Reviews, 14(6), 371-378. https://doi.org/10.1016/j.smrv.2009.12.002

Ortega, F. B., Chillón, P., Ruiz, J. R., Delgado, M., Albers, U., Alvarez-Granda, J. L., Marcos, A., Moreno, L. A. og Castillo, M. J. (2010). Sleep patterns in Spanish adolescents: Associations with TV watching and leisure-time physical activity. European Journal of Applied Physiology, 110(3), 563-573. https://doi. org/10.1007/s00421-010-1536-1

Philbrook, L. E., Saini, E. K., Fuller-Rowell, T. E., Buckhalt, J. A. og El-Sheikh, M. (2020). Socioeconomic status and sleep in adolescence: The role of family chaos. Journal of Family Psychology, 34(5), 577-586. https://doi.org/10.1037/fam0000636

Phillips, A. J. K., Clerx, W. M., O’Brien, C. S., Sano, A., Barger, L. K., Picard, R. W., Lockley, S. W., Klerman, E. B. og Czeisler, C. A. (2017). Irregular sleep/wake patterns are associated with poorer academic performance and delayed circadian and sleep/wake timing. Scientific Reports, 7(1), 3216. https://doi.org/10.1038/ s41598-017-03171-4

Phillips, M. L. (2009). Circadian rhythms: Of owls, larks and alarm clocks. Nature, 458(7235), 142-144. https://doi.org/10.1038/458142a

Rao, U., Hammen, C. L. og Poland, R. E. (2009). Ethnic differences in electroencephalographic sleep patterns in adolescents. Asian Journal of Psychiatry, 2(1), 17-24. https://doi.org/10.1016/j.ajp.2008.12.003

Roberts, R. E., Roberts, C. R. og Chan, W. (2006). Ethnic differences in symptoms of insomnia among adolescents. Sleep, 29(3), 359-365. https://doi.org/10.1093/sleep/29.3.359

Rognvaldsdottir, V., Gudmundsdottir, S. L., Brychta, R. J., Hrafnkelsdottir, S. M., Gestsdottir, S., Arngrimsson, S. A., Chen, K. Y. og Johannsson, E. (2017). Sleep deficiency on school days in Icelandic youth, as assessed by wrist accelerometry. Sleep Medicine, 33, 103-108. https://doi.org/10.1016/j.sleep.2016.12.028

Rúnar Vilhjálmsson. (2011). Fjölskyldugerð, aðhald og stuðningur foreldra og áfengisnotkun unglinga. I Ása Guðný Ásgeirsdóttir, Helga Björnsdóttir og Helga Ólafs (ritstjórar), Rannsóknir i félagsvisindum XII (bls. 473-479). Félagsvísindastofnun. 
Short, M. A., Gradisar, M., Lack, L. C., Wright, H. R., Dewald, J. F., Wolfson, A. R. og Carskadon, M. A. (2013). A cross-cultural comparison of sleep duration between US and Australian adolescents: The effect of school start time, parent-set bedtimes, and extracurricular load. Health Education \& Behavior, 40(3), 323-330. https://doi.org/10.1177/1090198112451266

Smith, C. S., Folkard, S., Schmieder, R. A., Parra, L. F., Spelten, E., Almiral, H., Sen, N., Sahu, S., Perez, L. M. og Tisak, J. (2002). Investigation of morning-evening orientation in six countries using the preferences scale. Personality and Individual Differences, 32(6), 949-968. https://doi.org/10.1016/S0191-8869(01)00098-8

Spaeth, A. M., Dinges, D. F. og Goel, N. (2013). Effects of experimental sleep restriction on weight gain, caloric intake, and meal timing in healthy adults. Sleep, 36(7), 981-990. https://doi.org/10.5665/sleep.2792

Stahlmann, K., Hebestreit, A., DeHenauw, S., Hunsberger, M., Kaprio, J., Lissner, L., Molnár, D., Ayala-Marín, A. M., Reisch, L. A., Russo, P., Tornaritis, M., Veidebaum, T., Pohlabeln, H. og Bogl, L. H. (2020). A cross-sectional study of obesogenic behaviours and family rules according to family structure in European children. International Journal of Behavioral Nutrition and Physical Activity, 17(1), 32. https://doi. org/10.1186/s12966-020-00939-2

Stutz, J., Eiholzer, R. og Spengler, C. M. (2019). Effects of evening exercise on sleep in healthy participants: A systematic review and meta-analysis. Sports Medicine, 49(2), 269-287. https://doi.org/10.1007/s40279018-1015-0

Tarokh, L., Saletin, J. M. og Carskadon, M. A. (2016). Sleep in adolescence: Physiology, cognition and mental health. Neuroscience \& Biobehavioral Reviews, 70, 182-188. https://doi.org/10.1016/j.neubiorev.2016.08.008

Thorleifsdottir, B., Bjornsson, J. K., Benediktsdottir, B., Gislason, T. og Kristbjarnarson, H. (2002). Sleep and sleep habits from childhood to young adulthood over a 10-year period. Journal of Psychosomatic Research, 53(1), 529-537. https://doi.org/10.1016/s0022-3999(02)00444-0

Torsheim, T., Cavallo, F., Levin, K. A., Schnohr, C., Mazur, J., Niclasen, B. og Currie, C. (2016). Psychometric validation of the revised family affluence scale: A latent variable approach. Child Indicators Research, 9, 771-784. https://doi.org/10.1007/s12187-015-9339-x

Troxel, W. M., Lee, L., Hall, M. og Matthews, K. A. (2014). Single-parent family structure and sleep problems in black and white adolescents. Sleep Medicine, 15(2), 255-261. https://doi.org/10.1016/j.sleep.2013.10.012

Van Cauter, E., Spiegel, K., Tasali, E. og Leproult, R. (2008). Metabolic consequences of sleep and sleep loss. Sleep Medicine, 9(suppl. 1), S23-S28. https://doi.org/10.1016/s1389-9457(08)70013-3

Weiss, A., Xu, F., Storfer-Isser, A., Thomas, A., Ievers-Landis, C. E. og Redline, S. (2010). The association of sleep duration with adolescents' fat and carbohydrate consumption. Sleep, 33(9), 1201-1209. https://doi. org/10.1093/sleep/33.9.1201

Wheaton, A. G., Ferro, G. A. og Croft, J. B. (2015). School start times for middle school and high school students - United States, 2011-12 school year. Morbidity Mortal Weekly Report, 64(30), 809-813. https:// doi.org/10.15585/mmwr.mm6430a1

Wolfson, A. R., Carskadon, M. A., Acebo, C., Seifer, R., Fallone, G., Labyak, S. E. og Martin, J. L. (2003). Evidence for the validity of a sleep habits survey for adolescents. Sleep, 26(2), 213-216. https://doi.org/10.1093/ sleep/26.2.213

Wright, K. P., Lowry, C. A. og Lebourgeois, M. K. (2012). Circadian and wakefulness-sleep modulation of cognition in humans. Frontiers in Molecular Neuroscience, 5, 50. https://doi.org/10.3389/fnmol.2012.00050

Zhang, J., Paksarian, D., Lamers, F., Hickie, I. B., He, J. og Merikangas, K. R. (2017). Sleep patterns and mental health correlates in US adolescents. Journal of Pediatrics, 182, 137-143. https://doi.org/10.1016/j. jpeds.2016.11.007

Guðrún Kristjánsdóttir, Rúnar Vilhjálmsson og Vaka Rögnvaldsdóttir. (2021).

Svefnlengd íslenskra skólabarna.

Netla - Veftímarit um uppeldi og menntun: Sérrit 2021 - HBSC og ESPAD rannsóknirnar

Sótt af http://netla.hi.is/serrit/2021/HBSC_ESPAD_rannsoknir/03.pdf

DOI: https://doi.org/10.24270/serritnetla.2021.7 